Classroom reports

\title{
How students understand smaller fractions divided by greater fractions?
}

\section{Kamirsyah Wahyu ${ }^{1}$}

\begin{abstract}
This paper discusses how $5^{\text {th }}$-grade students understand quotative fractions division or smaller fractions divided by greater fractions in specific. A context-based mathematics task, making posters, was developed and implemented in two Realistic Mathematics Education (RME)-based lessons involving 6 students and 28 students. The analysis of students' group discussion and works on the task reveal that the students initially experienced difficulties in determining how many posters can be made using $1 / 2$ of one paper if one poster requires $3 / 4$ of a paper. To support students' understanding, a task, which carefully sequences fractions division content and utilizes contexts that can be easily modeled is required.
\end{abstract}

\section{Keywords Making posters, Fraction division, Quotative, Realistic Mathematics Education}

\begin{abstract}
Abstrak Artikel ini membahas bagaimana siswa kelas 5 sekolah dasar membangun pemahaman konsep pembagian pecahan kuotatif atau secara khusus membagi bilangan pecahan yang lebih kecil dengan pecahan yang lebih besar. Tugas matematika berbasis konteks membuat poster dikembangkan dan diujicobakan melalui 2 tahap pembelajaran berorientasi Pendidikan Matematika Realistik yang melibatkan 6 siswa dan 28 siswa. Hasil analisis diskusi kelompok siswa dan jawaban tugas matematika menunjukkan bahwa pada awalnya siswa mengalami kesulitan ketika menentukan berapa poster yang bisa dibuat dari $1 / 2$ kertas jika satu poster membutuhkan $3 / 4$ kertas. Untuk mendukung pemahaman siswa, diperlukan serangkaian tugas matematika yang mengurutkan konten pembagian pecahan dan berbasis konteks yang mudah dimodelkan.
\end{abstract}

Kata kunci Membuat poster, Pembagian pecahan, Pendidikan Matematika Realistik

\section{Pendahuluan}

Pembagian pecahan merupakan topik matematika yang sangat sulit bagi guru dan siswa di sekolah dasar (SD). Hal ini dikarenakan karakteristik pembagian pecahan (Prediger, 2006) yang tersusun oleh operasi pembagian dan bilangan pecahan. Pembagian merupakan operasi matematika yang sangat kompleks dan pecahan merupakan bilangan yang tidak mudah dipahami dalam aritmatika (Streefland, 1991; Ma, 2010). Sebagai contoh, pada pembagian bilangan asli, hasil pembagian selalui lebih kecil atau sama dengan bilangan yang dibagi dan pembagi. Namun, pada pembagian pecahan, hal tersebut tidak selalu berlaku, misalnya $2 \div 1 / 2$ hasilnya 4 . Upaya membantu siswa untuk membangun pemahaman pada materi pembagian pecahan (Misalnya, Wahyu et al., 2020) dan mendukung guru untuk mengajarkan materi tersebut secara konseptual (Wahyu, 2020) harus terus diupayakan secara berlanjut. Artikel ini, sebagai bagian penelitian berbasis pengembangan (Design Research, Bakker, 2018) yang bertujuan mendukung siswa

\footnotetext{
${ }^{1}$ Program Studi Tadris Matematika, Universitas Islam Negeri Mataram, Jln. Gajah Mada 100 Mataram 83116,kwahyu@uinmataram.ac.id
} 
memahami pembagian pecahan di SD, diharapkan sebagai salah satu upaya untuk membantu guru matematika mempelajari bagaimana mengajarkan pembagian pecahan secara konseptual.

\section{Pembagian pecahan}

Ada dua jenis pembagian pecahan, yaitu pembagian pecahan partitif atau disebut juga pembagian adil (fair-sharing) dan pembagian kuotatif atau dikenal juga dengan istilah pembagian dengan pengurangan berulang atau pengukuran (measurement fraction divisions) (Gregg \& Greeg, 2007).

\section{Contoh pembagian pecahan kuotatif}

"Dwi memiliki $4 \mathrm{~kg}$ tepung yang akan dimasukan ke dalam kotak. Satu kotak berisi $2 / 3$ kg tepung, berapa kotak yang Dwi butuhkan?"

\section{Contoh pembagian pecahan partitif}

"Dwi memiliki 2/3 bagian kue tar yang akan dibagikan sama besar kepada 2 orang temannya, berapa bagian kue tar yang diperoleh masing-masing teman Dwi?"

Dalam pembagian pecahan partitif, banyak kelompok diketahui (2 orang teman Dwi) tetapi ukuran setiap kelompok belum diketahui (bagian kue yang diperoleh setiap teman Dwi). Sebaliknya, ukuran kelompok diketahui (satu kotak berisi $2 / 3 \mathrm{~kg}$ tepung) namun banyaknya kelompok (jumlah kotak yang dibutuhkan untuk menampung $4 \mathrm{~kg}$ tepung) belum diketahui dalam pembagian pecahan kuotatif. Tugas membuat poster dalam penelitian ini merujuk pada konsep kuotatif pembagian pecahan.

\section{Tugas matematika berbasis konteks}

Tugas matematika memiliki peran penting dalam mendukung siswa membangun pengetahuan matematika (Simon \& Tzur, 2004; Sullivan, Clarke, \& Clarke, 2012). Oleh sebab itu, penelitian ini mengembangkan tugas matematika berbasis konteks membuat poster untuk membantu siswa memahami konsep pembagian pecahan.

\section{Membuat Poster}

Anna akan membuat beberapa poster dengan tema Honest is My Success yang akan ditempel di majalah dinding sekolah. Setiap poster dibuat dengan ukuran berbeda menggunakan kertas karton. Bantulah Anna untuk menentukan banyak poster yang bisa dibuat dengan kertas yang tersedia.

a. Poster I membutuhkan 1/2 bagian kertas. Berapa banyak poster yang bisa dibuat dari 1 kertas?

b. Poster II membutuhkan $1 / 3$ bagian kertas. Berapa banyak poster yang bisa dibuat dari $2 / 3$ kertas?

c. Poster III membutuhkan $1 / 2$ bagian kertas. Berapa banyak poster yang bisa dibuat dari $3 / 4$ kertas?

d. Poster IV membutuhkan $3 / 4$ bagian kertas. Berapa banyak poster yang bisa dibuat dari $1 / 2$ kertas?

\section{Menggunakan model}

Model merupakan representasi eksternal (Goldin \& Shteingold, 2001) yang berfungsi sebagai jembatan pengetahuan informal dan pengetahuan formal siswa. Penggunaan model atau 
representasi sangat dianjurkan dalam mempelajari pecahan (van de Walle, Karp, \& BayWilliams, 2010). Ada tiga jenis model yang sering digunakan dalam pecahan yaitu garis bilangan, luas, dan sekelompok objek (Petit et al., 2016). Dalam pembelajaran, siswa didorong untuk menggunakan model yang berbeda dalam menyelesaikan tugas matematika (membuat poster). Dalam hal ini, siswa tidak diarahkan untuk langsung menggunakan algoritma atau rumus. Menurut Fosnot dan Dolk (2001), konteks yang digunakan dalam merancang tugas matematika harus mendukung siswa menggunakan model. Tugas membuat poster sangat memungkinkan siswa memodelkan kertas karton dalam bentuk gambar sebagai langkah awal menyelesaikan permasalahan tersebut.

\section{Mengurutkan konten pembagian pecahan}

Selain tugas matematika yang digunakan berbasis konteks dan memungkinkan siswa untuk menggunakan model, urutan konten materi dalam tugas matematika juga mendukung siswa memahami materi. Contohnya, siswa akan lebih mudah memahami $2 \div 1 / 2$ daripada $1 / 2 \div 3 / 4$ ketika pertama belajar pembagian pecahan (Wahyu, Amin, \& Lukito, 2017; Wahyu et al., 2020). Tugas matematika yang dikembangkan dalam penelitian ini mengurutkan pembagian pecahan kuotatif dari yang lebih mudah sampai yang sulit.

\section{Konteks penelitian}

Sebelum membahas hasil penerapan tugas matematika di dua tahap pembelajaran, perlu dijelaskan dahulu terkait karakateristik kelas. Informasi ini penting agar guru yang berencana menggunakan tugas matematika yang dikembangkan pada kelas yang berbeda memiliki gambaran apa yang perlu dipersiapkan. Sebelum pelaksanan penelitian, dilakukan observasi kelas dan wawancara dengan guru secara intensif. Adapun informasi yang diperoleh dan penyesuain yang dilakukan sebagai berikut.

\section{Karakteristik kelas}

$\checkmark$ Sekolah tempat penelitian merupakan sekolah Islam terpadu sehingga memiliki normal sosial tersediri; posisi duduk siswa terpisah dengan siswi

$\checkmark$ Siswa belum dikenalkan representasi yang berbeda untuk pecahan. Penjumlahan dan pengurangan pecahan fokus pada penerapan algoritma.

$\checkmark$ Pembelajaran matematika tidak dimulai dengan permasalahan kontekstual tetapi pengenalan dan penggunaan rumus. Soal cerita diberikan di akhir pembelajaran.

$\checkmark$ Pembelajaran matematika sudah berpusat pada siswa. Siswa aktif dalam diskusi kelompok.

\section{Penyesuaian aktivitas pembelajaran}

$\checkmark$ Pembagian kelompok berdasarkan jenis kelamin.

$\checkmark$ Siswa dikenalkan tiga model untuk merepresentasikan pecahan sebelum pembelajaran.

$\checkmark$ Pembelajaran dimulai dengan tugas matematika berbasis konteks untuk didiskusikan dalam kelompok dan bersama guru setelah selesai dalam kelompok

Tugas matematika membuat poster diberikan pada pertemuan kelima, empat pertemuan sebelumnya siswa sudah diberikan tugas matematika berbasis konteks yang berkaitan dengan 
konten pembagian pecahan untuk menentukan poster I-III. Tugas matematika diberikan kepada siswa dalam bentuk Lembar Kerja Siswa (LKS) yang berisi langkah-langkah pendukung penyelesaian tugas. Peneliti bertindak sekaligus sebagai guru karena guru kelas yang mengajar matematika belum siap mengajar dengan rancangan penelitian yang dibuat dan memilih mengamati proses pembelajaran.

\section{Ujicoba pertama}

Pada ujicoba pertama, 6 siswa (3 laki-laki, 3 perempuan) yang terlibat dibagi menjadi dua kelompok berdasarkan gender. Keenam siswa memiliki kemampuan matematika berbeda (tinggi, sedang, dan rendah). Pemilihan siswa dengan kemampuan berbeda bertujuan menguji apakah tugas matematika yang dirancang bisa digunakan tidak hanya untuk siswa dengan kemampuan matematika tinggi.

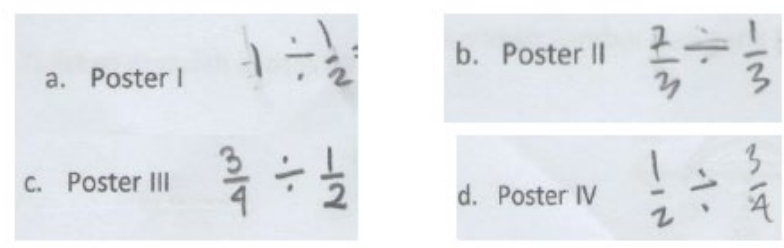

Gambar 1. Kalimat matematika untuk poster I-IV

Gambar 1 menunjukkan jawaban siswa (dalam kelompok) dalam menentukan kalimat matematika untuk poster I-IV. Siswa di kedua kelompok tidak mengalami kesulitan mengidentifikasi permasalahan tersebut sebagai pembagian pecahan karena sudah melalui empat pertemuan. Gambar 2 menunjukkan dua model yang digunakan siswa untuk menentukan poster I. Siswa dengan kemampuan sedang dan rendah belum bisa secara langsung menentukan poster III karena permasalahan tersebut melibatkan unit dalam pecahan. Dari 3/4 bagian kertas tersedia, hanya bisa dibuat 1 poster utuh dan tersisa $1 / 4$ bagian. Siswa kemungkinan akan menjawab $1 \frac{1}{4}$ poster jika tidak memahami unit pecahan. Namun, jika siswa memahami, poster yang bisa dibuat yaitu $1 \frac{1}{2}$.
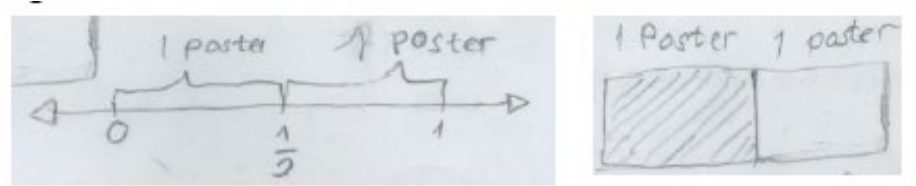

Gambar 2. Garis bilangan dan model luas untuk menentukan poster I

Semua siswa tidak memiliki ide untuk menentukan poster IV menggunakan model. Hal ini ditunjukkan oleh kutipan percakapan berikut.

\section{Transkrip 1}

Guru

Siswa

Apakah memiliki ide untuk menentukan poster IV?

Guru $\quad$ Perhatikan dengan seksama pert
Ada bertas yang tersedia? ...(tidak ada respon verbal, tetapi gestur siswa menunjukkan bahwa mereka belum memiliki ide apapun) 


$\begin{array}{lll}\text { Siswa } & : & 1 / 2 \\ \text { Guru } & : & \text { Untuk membuat satu poster, berapa kertas yang dibutuhkan? } \\ \text { Siswa } & : & 3 / 4 \\ \text { Guru } & : \text { Apakah kertas yang tersedia cukup untuk membuat satu poster? } \\ \text { Siswa } & : \text {.. (belum ada jawaban, siswa saling menatap satu sama lain) } \\ \text { Guru } & : \text { Baik. Perhatikan kertas ini (guru menunjukkan kertas karton yang } \\ & \text { sudah disiapkan untuk membantu ilustrasi). Kita memiliki 1/2 } \\ & \text { bagian kertas tetapi satu poster membutuhkan 3/4 bagian kertas. } \\ & \text { Dapatkah kalian menunjukkan 3/4 di kertas ini? } \\ \text { Siswa } & : \text { Itu pak (Siswa bisa menandai 3/4 bagian kertas) } \\ \text { Guru } & : \text { Bagus, apakah kertas yang tersedia cukup untuk membuat satu } \\ & \text { poster? } \\ \text { Siswa } & : \text { Tidak (Seorang siswa menjelaskan bahwa 3/4 lebih besar dari 1/2) }\end{array}$

Kemudian, siswa diminta untuk memperhatikan kembali model luas daerah yang sudah dibuat dan mengarsir 3/4 (kertas yang dibutuhkan untuk 1 poster). Kedua transkrip tersebut menunjukkan bagaimana strategi guru untuk membantu siswa memahami pembagian pecahan yang lebih kecil oleh bilangan pecahan yang lebih besar $(1 / 2 \div 3 / 4)$ melalui model luas. Gambar 3 menunjukkan jawaban kelompok perempuan.

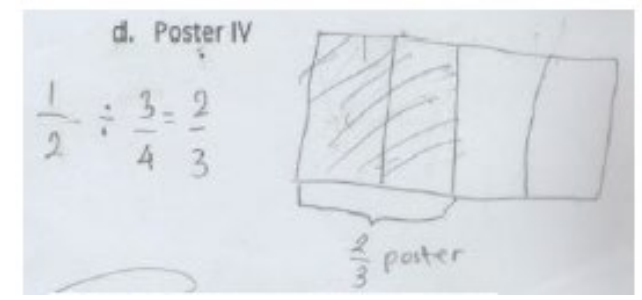

Gambar 3. Menentukan poster IV menggunakan model luas

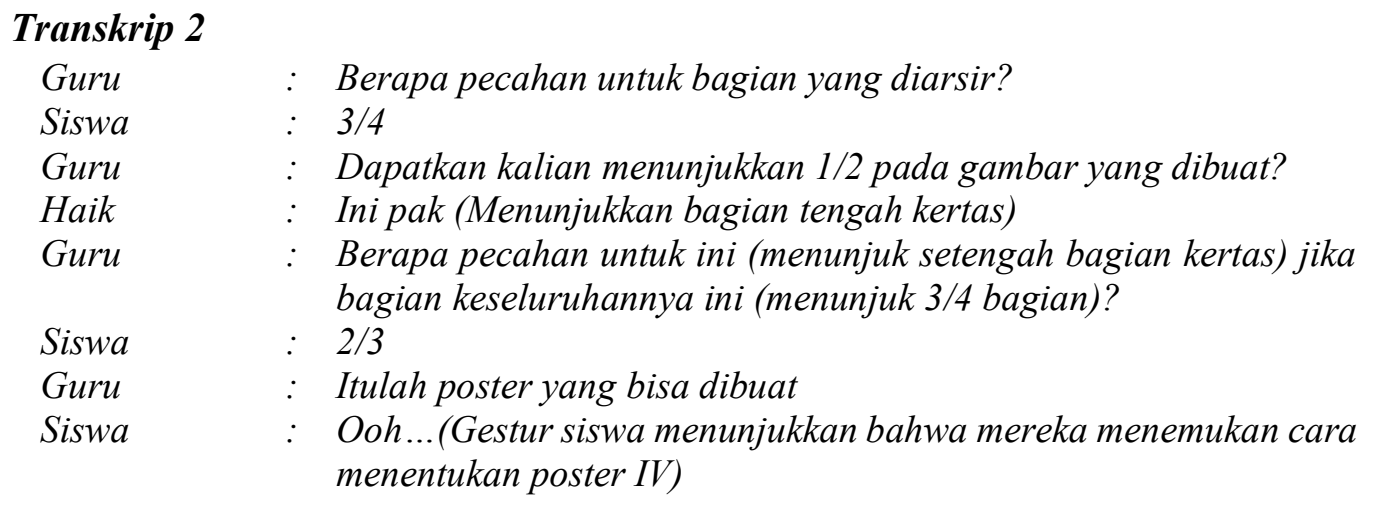

\section{Ujicoba kedua}

Ujicoba kedua melibatkan 28 siswa yang dibagi menjadi beberapa kelompok, satu kelompok terdiri dari 4-5 orang. Setiap kelompok terdiri dari siswa dengan kemampuan matematika yang heterogen. Karena keterbatasan perangkat pendukung penelitian seperti kamera perekam, jumlah guru, dan jumlah siswa, satu kelompok yang tediri dari 5 siswa lakilaki dipilih menjadi focused group. Satu kamera digunakan secara khusus untuk merekam aktivitas kelompok tersebut. Dalam hal ini, guru juga memfasilitasi diskusi di kelompok yang lain. 
Pada ujicoba kedua, siswa dalam kelompok juga tidak mengalami kesulitan untuk menentukan kalimat matematika untuk poster I-III tetapi hanya beberapa kelompok dapat secara langsung menentukan poster yang bisa dibuat melalui model (Gambar 4). Sama seperti ujicoba pertama, semua kelompok mengalami kesulitan menentukan poster IV bahkan hanya tiga kelompok yang bisa menentukan kalimat matematika yang tepat $(1 / 2 \div 3 / 4)$. Kelompok yang lain menulis kalimat matematika yang terbalik $(3 / 4 \div 1 / 2)$. Dengan strategi yang sama, guru membantu siswa menentukan poster IV menggunakan model (Gambar 5).

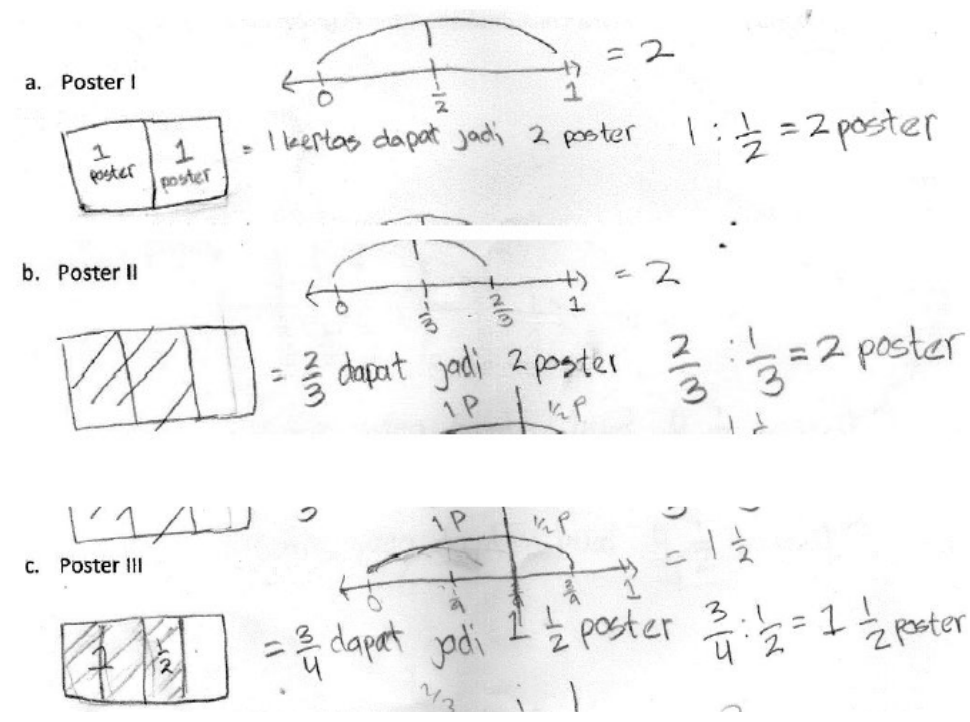

Gambar 4. Model luas dan garis bilangan digunakan untuk menentukan poster I-III

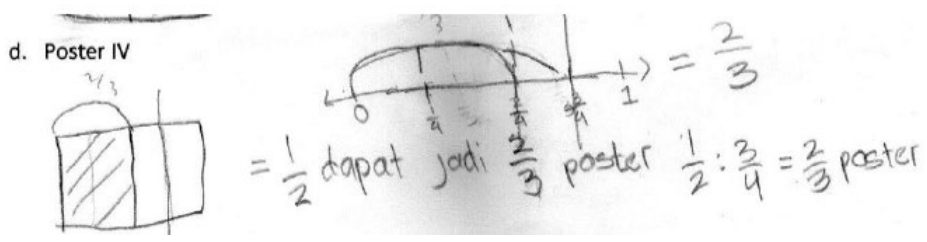

Gambar 5. Siswa menggunakan model luas dan garis bilangan untuk menentukan poster IV

\section{Bagaimana siswa membangun pemahaman?}

Penggunaan tugas berbasis konteks membuat poster, model, dan urutan konten pecahan sangat membantu siswa memahami pembagian pecahan yang lebih kecil oleh pecahan yang lebih besar. Untuk memahami $1 / 2 \div 3 / 4$, siswa sebaiknya terlebih dahulu memahami $1 \div 1 / 2,2 / 3 \div 1 / 3$, dan $3 / 4 \div 1 / 2$. Menentukan berapa poster yang bisa dibuat dari 1 kertas karton jika satu poster membutuhkan $1 / 2$ bagian kertas tentu lebih mudah daripada menentukan berapa poster yang bisa dibuat dari $2 / 3$ bagian kertas yang tersedia jika satu poster memerlukan $1 / 3$ bagian kertas dan seterusnya. Konten materi yang diurutkan dengan memperhatikan tingkat kesulitan membantu siswa membangun pengetahuan matematika. 


\section{Catatan penutup}

Salah satu tantangan memperbaiki pembelajaran matematika yang berorientasi pada pengembangan pemahaman konsep adalah siswa yang sudah terbiasa dengan pembelajaran prosedural. Dalam hal ini, siswa belum terbiasa menyelesaikan tugas matematika berbasis konteks di awal pembelajaran sebagai bagian penting memahami materi yang diajarkan guru. Selain itu, siswa juga belum terbiasa memberikan alasan (reasoning) atau justifikasi terkait hasil kerjanya dan cenderung berorientasi hasil (apakah jawabannya sudah benar atau tidak) (Wahyu, 2015). Mengembangkan tugas matematika berbasis konteks dan dengan tingkat kognitif tinggi (Stein \& Smith, 1998) seperti membuat poster dalam penelitian ini akan membantu guru mengembangkan pemahaman matematika siswa. Penelitian ini fokus pada mengembangkan pemahaman konseptual melalui penggunaan model atau tidak mengenalkan algoritma (menyamakan penyebut dan dibalik-dikali) untuk menentukan hasil pembagian pecahan. Kedua algoritma tersebut juga sangat berguna untuk siswa, namun menjadi tidak bermakna jika tanpa didasari oleh pemahaman kenapa algoritma tersebut bisa digunakan. Dibutuhkan penelitian lebih lanjut untuk memahami bagaimana siswa menghubungkan model yang digunakan untuk memahami pembagian pecahan dengan algoritma tersebut.

\section{Referensi}

Bakker, A. (2018). Design research in education: A practical guide for early career researchers. Routledge: London.

Fosnot, C.T. \& Dolk, M. (2001). Young mathematicians at work: Constructing multiplication and division. Heinemann: Portsmouth.

Goldin, G. \& Shteingold, N. (2001). System of representations and the development of mathematics concept. In A.A. Cuoco \& F.R. Curcio (Eds.). The roles of representation in school mathematics. 2001 Yearbook (pp.1-23). Reston, VA: NCTM.

Gregg, J., \& Gregg, D. U. (2007). Measurement and fair-sharing models for dividing fractions. Mathematics Teaching in the Middle School, 12(9), 490-496.

Ma, L. (2010). Knowing and teaching elementary mathematics: Teachers' understanding of fundamental mathematics in China and the United States. New York: Routledge.

Petit, M. M., Laird, R. E., Marsden, E. L., \& Ebby, C. B. (2016). A focus on fractions: Bringing research to the classroom (2nd edition). New York: Routledge.

Prediger, S. (2006). Continuities and discontinuities for fractions: A proposal for analysing in different levels. In Novotna, J. et al. (Eds.). Proceeding of the 30th PME, Prag 2006, 4-377-384.

Simon, M. A., \& Tzur, R. (2004). Explicating the role of mathematical tasks in conceptual learning: An elaboration of the hypothetical learning trajectory. Mathematical Thinking and Learning, 6(2), 91104. Doi: $10.1207 / \mathrm{s} 15327833 \mathrm{mtl} 0602 \_2$

Stein, M. K., \& Smith, M. S. (1998). Mathematical tasks as a framework for reflection: From research to practice. Mathematics Teaching in the Middle School, 3(4), 268-275.

Streefland, L. (1991). Fractions in realistic mathematics education: A paradigm of developmental research. Dordrecht: Kluwer Academic Publishers.

Sullivan, P., Clarke, D., \& Clarke, B. (2012). Teaching with tasks for effective mathematics learning. Springer Science \& Business Media.

van de Walle, J.A., Karp, K.S., \& Bay-Williams, J.M. (2010). Elementary and middle school mathematics: Teaching developmentally (7th edition). Boston: Allyn \& Bacon.

Wahyu, K. (2015). Changing mathematics classroom setting: Looking into students' response and performance in learning. In L.R.T Savalas et al (Eds.), The Proceeding of International Conference on Mathematics, Science, and Education Vol. 3 (pp.113-121). Mataram: FKIP Universitas Mataram. 
Wahyu, K.

Wahyu, K., Amin, S. M., \& Lukito, A. (2017). Motivation cards to support students' understanding on fraction division. International Journal on Emerging Mathematics Education, 1(1), 99-120. Doi: 10.12928/ijeme.v1i1.5760.

Wahyu, K. (2020). Specialized fractions division knowledge: A proposed model. In Inprasitha, M., Changsri, N. \& Boonsena, N. (Eds). Proceedings of the 44th Conference of the International Group for the Psychology of Mathematics Education, Interim Vol, pp. 648-656. Khon Kaen, Thailand: PME.

Wahyu, K., Kuzu, T.E., Subarinah, S., Ratnasari, D., \& Mahfudy, S. (2020). Partitive fraction division: Revealing and promoting primary students' understanding. Journal on Mathematics Education, 11(2), 237-258. Doi: 10.22342/jme.11.2.11062.237-258. 